\title{
Solid Waste Generation from Healthcare Facilities in Surabaya City Indonesia
}

\author{
Wilujeng A Susi ${ }^{1, *}$, Damanhuri Enri ${ }^{2}$, and Mochammad Chaerul $^{2}$ \\ ${ }^{1}$ Doctoral Student, Environmental Engineering Department, Institut Teknologi Bandung, Bandung, Indonesia \\ ${ }^{2}$ Environmental Engineering Department, Institut Teknologi Bandung, Bandung, Indonesia
}

\begin{abstract}
This research objective is to obtain information on solid waste generated by clinics, community health centers and hospitals in Surabaya and its treatment. The waste generation information in each health facilities is acquired by 5 day-sampling, while survey by questionnaire was performed to know how they manage their waste as well as to get information on the number of beds and patients. The solid waste consists of medical and non-medical/general waste. The medical waste generation is 163,9 tons/month where $97,1 \%$ of it (158 tons/month) comes from hospitals. Community health centers and clinics contribute 1,1 tons/month and 3,5 tons/month, respectively. Only 29,6\% of hospitals medical waste was treated with onsite incinerators. As much as $66 \%$ of hospitals medical waste was not had incinerators, community health centers and clinics $0,7 \%$ and $0,6 \%$ of the waste is treated with incinerator by third parties. Hospitals medical waste from used packaging $(1 \%)$ can be reused, while the treatment of $1,5 \%$ medical waste from clinics is unknown. Non-medical waste generation is 431 tona/month, where $99,2 \%$ of it 427,5 tons/month comes from hospitals. Community health centers and clinics generate 1,4 ton/month and 2,1 ton/month nonmedical waste, respectively.
\end{abstract}

\section{Introduction}

Health care facilities activities, research centers and laboratories related to medical procedures produce health care waste. In addition, it includes waste from "small" or "spreading" sources such as waste from outpatient treatments (such as dialysis, insulin injection, recovery treatments). The waste consists of $75-90 \%$ waste that are some recommendations related to health care waste start from handling, collecting, transporting, treatment and disposal [2]. The quantity of waste is the basic information in a management plan. Sufficient and accurate information about the quantity and composition of waste is the key to implement waste management plan successfully [3].

Indonesian Ministry of Environment and Forestry Indonesia No.56 Year 2015 on the Technical Procedures and Requirements for Management of Hazardous and Toxic Waste Materials from Health Care Facilities regulates hazardous solid waste in health service facilities in Indonesia. It regulates waste from minimizing and sorting, storing, transporting, processing, and burying hazardous and toxic waste. The Ministry of Health as an institution that regulates health care facilities published regulations related to solid waste management as part of Regulation of the Minister of Health No. 7 of 2019 on hospital environmental health.

Surabaya is the second largest city in Indonesia, with a large number of health service facilities to serve nearly three million people. Therefore, the researcher calculated

Corresponding author: wilujeng_susi@yahoo.com non-risk, harmless and resembles household waste, and then the remaining of $10-25 \%$ is hazardous and causing health and environmental risks [1]. Regulations related to sustainable management of health care waste remain unclear and there is no policy related to that matter. However, there

are

the resulting solid waste to find management recommendations for minimizing risks and improving environmental quality. This study is to calculate the amount of solid waste of health service facilities in Surabaya in both medical and non-medical categories.

\section{Material and Methods}

The study location was in the health service facilities in Surabaya, Indonesia, including community health centers, clinics and hospitals. Data collection used secondary data survey included the number of bed and treated patients in each health service facility in a year, which became the research sample: 16 health centers, 17 clinics, and 12 hospitals. Questionnaires related to how to sort, store, solid waste transportation and treatment, and direct observation during the waste sample measurement revealed the solid waste management used. There were two types of solid waste sample, namely medical waste and non-medical or general waste.

Sample measurement took place during the five working days in July-August 2017, using direct 
weighing in the source of solid waste to determine waste production in $\mathrm{kg} / \mathrm{bed} / \mathrm{day}$ or $\mathrm{kg} /$ patient/day. This study used descriptive statistics. The number of patients in health care facilities and the number of hospital beds was obtained from secondary data from the Surabaya City Health Office. The researcher used Microsoft Excel in weighing data and other secondary data to determine the mass balance of solid waste.

\section{Results}

\subsection{Solid Waste Management of Health Care Facilities in Surabaya}

Surabaya has an area of 33,306 hectares, with a population of 2.9 million people and health care facilities in the form of 62 Community Health Centers, 262 clinics and 59 hospitals are divided into several hospital classes, the number of bed is 8327 beds, in a day average served 4350 inpatients and 16700 outpatient.

Stages of solid waste management in hospitals were minimizing and segregation, storage, transportation, treatment and landfill. A fault in a particular stage would disrupt the entire management system. The segregation or sorting process divided waste into general waste and medical waste. General waste is non-hazardous solid waste from non-medical activities, while medical waste is toxic and hazardous waste from medical activities. Medical solid waste in hospitals came from the outpatient or polyclinic services, laboratories, emergency rooms, inpatient rooms, delivery rooms and pharmaceutical warehouses. The waste is in the form of used gauze swabs, syringes, tubes, catheters, gloves, masks, bottles/ampoules, sanitary pads, cotton/bandages contaminated with blood/body fluids, slide glasses, lancet, and expired medicines. Health centers and clinics served outpatients who produced the same medical solid waste as the polyclinic services in the hospital. Hazardous solid waste was contained in special colored containers with special signs and symbols in medical treatment rooms, then collected and stored in hospitals.

Hospitals had incinerators for burning waste, surprisingly, only four hospitals had incineratorss and they transport the residue to the next treatment by a third party. Two hospitals managed the remaining packages that are uncontaminated by blood, body fluids, and infections, such as infused bottles and hemodialysis jerry cans, with disinfection and enumeration to be recycled plastic waste.

The medical waste generated by Surabaya's health facilities amounted to $0.953 \mathrm{~kg} / \mathrm{bed} /$ day for A class hospitals, $0.824 \mathrm{~kg} / \mathrm{bed} /$ day for B class hospitals and $0.304 \mathrm{~kg} / \mathrm{bed} /$ day for $\mathrm{C}$ class hospitals [4], clinical medical waste was $0.07 \mathrm{~kg} /$ patient [5] whereas for the community health center was $0.02 \mathrm{~kg} /$ patien[6].

The management of non-hazardous solid waste or domestic waste included the leftovers of patients, paramedic, employees, canteens, office activities and kitchens for inpatients. There was a plastic bag for waste in each room and the janitor collected it twice a day. The janitor placed waste from each room in clinics and health centers in containers or recycle bins in front of the building. In addition, officers transported the waste to the nearest garbage center owned by the government. Officials of small hospitals collected waste to the nearest waste center using cart or four-wheeled vehicles, while large hospitals sent the waste directly to the final processing site in Benowo, Surabaya. One hospital had made an effort to recycle disaggregated plastic waste and composting for food scraps and kitchen waste.

\subsection{Solid Waste Balance of Health Care Facilities}

Solid waste generation multiplied by the number of patients in each health care facility shows the quantity of waste produced in one unit of time. Figure 1 shows Surabaya medical solid waste mass balance, while Figure 2 shows non-medical waste mass balance.

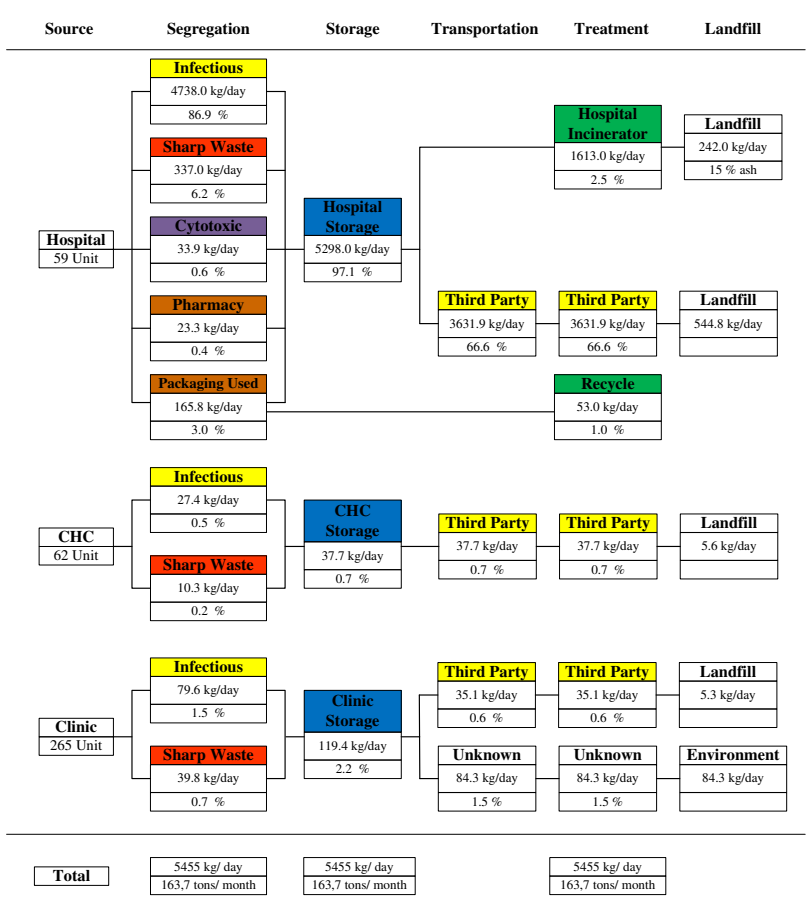

Fig. 1. Medical Waste Balance of Surabaya Health Facilities

Medical waste of Surabaya health facilities was $5,464.4 \mathrm{~kg} /$ day (163.9 tons/month). Then, medical waste of hospitals was $5,298.0 \mathrm{~kg} /$ day (158 tons/month), while medical waste of health centers and clinics were 37.7 $\mathrm{kg} /$ day (1.1 tons/month) and $119.4 \mathrm{~kg} /$ day $(3.5$ tons/month).

Medical waste management in Surabaya health facilities begins with collection. Medical waste of hospitals from the hospitals' landfill was $5,298 \mathrm{~kg} /$ day (158.9 tons/month), while medical waste of community health centers and clinics were $37.7 \mathrm{~kg} /$ day (1.1 tons/ month) and $119.4 \mathrm{~kg} /$ day (3.6 tons/month).

Some hospitals in Surabaya had independently conducted medical waste treatment with incinerators, namely Hospital A, Hospital B, Hospital G, and one of 
private hospitals with a processing capacity of 1,613 $\mathrm{kg}$ /day (108.9 tons/month). In addition, there was a processing by recycling the remaining packages by Hospital A by $53 \mathrm{~kg} /$ day (1.5 tons/month). Further, medical waste management in clinics that was cooperated with third parties and transported out of Surabaya was 3,631.9 kg/day (109.0 tons/month).

Community health centers processed their medical waste by third party and transported it out of Surabaya by $37.7 \mathrm{~kg} /$ day (1.1 tons/month). Clinics conducted medical waste treatment by transporting $35.1 \mathrm{~kg} /$ day $(1.1$ tons/month) of waste outside Surabaya by a third party. Some clinics did not cooperate with third parties $(70.6 \%)$. Therefore, they transported and managed the remaining waste by $84.3 \mathrm{~kg} /$ day ( 2.5 tons $/$ month).

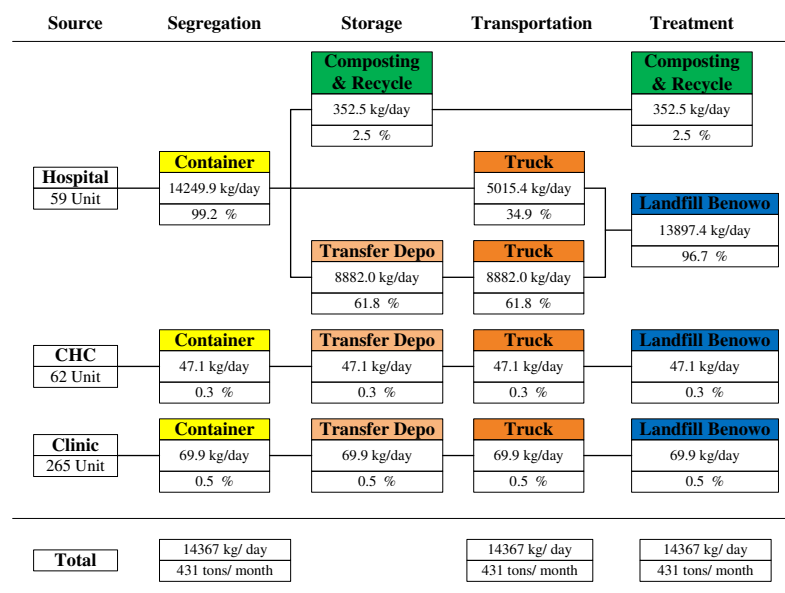

Fig. 2. Non-Medical/General Waste Balance of Surabaya Health Facilities

Based on Figure 2, non-medical waste production was $14,366.9 \mathrm{~kg} /$ day (431 tons/month). Hospitals contributed the largest amount of non-medical waste by 99.2\% among health facilities in Surabaya. Non-medical waste management taken by this far was on-site by composting and recycling, conducted by the largest hospital in Surabaya (Hospital A). Based on this research, health care facilities in Surabaya piled up $92.1 \%$ of non-medical waste directly at Benowo landfill.

Non-medical solid waste production was 14,366.9 $\mathrm{kg} /$ day (431 tons/month). Non-medical waste from the hospital was $14,249.9 \mathrm{~kg} /$ day (431 tons/month). Hospitals contributed the largest amount of non-medical waste, by $99.2 \%$ among health facilities in Surabaya. Non-medical waste from health centers and clinics were $47.1 \mathrm{~kg} /$ day (1.4 tons/month) and $69.9 \mathrm{~kg} / \mathrm{day}(2.1$ tons/month).

Health care facilities in Surabaya managed nonmedical waste by collecting it in temporary depo waste. Community health centers and clinics collected nonmedical waste by $47.1 \mathrm{~kg} /$ day (1.4 tons/month) and 69.9 $\mathrm{kg}$ /day (2.0 tons/month). Non-medical waste treatment conducted by hospitals so far was on-site treatment in the form of composting and recycling by Hospital A by $352.5 \mathrm{~kg} /$ day (10.5 tons/month). Some hospitals transported non-medical waste directly to Benowo
Landfill; they were Hospital A, Hospital B and Hospital E by $5,015.4 \mathrm{~kg} /$ day (150.4 tons/month). Based on this research, health facilities in Surabaya transported $97.5 \%$ of non-medical waste for final processing to Benowo landfill.

\section{Conclusions}

Health care facilities in Surabaya conducted solid waste management in accordance with applicable laws and regulations. The special management of solid waste in the medical category went through several stages, namely collection, storage, transportation, and processing as well as the stockpiling of processing products. Health care facilities in Surabaya collect and store non-medical solid waste then transport it to the final waste process in Benowo. There is only one hospital reduces and recycles waste.

The medical waste generation from health facilities in Surabaya is 163,9 tons/month where $97,1 \%$ of it comes from hospitals. Community health centers and clinics contribute 1,1 tons/month) and 3,5 tons/month, respectively. Only $29,6 \%$ of hospitals medical waste was treated with onsite incinerators. As much as $66 \%$ of hospitals medical waste was not had incinerators, community health centers and clinics $0,7 \%$ and $0,6 \%$ of the waste is treated with incinerator by third parties.Hospitals medical waste from used packaging (1\%) can be reused, while the treatment of $1,5 \%$ medical waste from clinics is unknown.

Non-medical waste generation is 431 tons/month, where $99,2 \%$ of it comes from hospitals. Community health centers and clinics generate 1,4 ton/month and 2,1 ton/month) non-medical waste, respectively. As much as $2,5 \%$ of non-medical waste form hospitals is composted and recycled, while $97,5 \%$ is transported and treated in municipal waste landfill in Benowo.

\section{References}

1. Chartier, Y., Emmanuel, J., Pieper, U., Rushbrook, P., Stringer, R., Townend, W., Wilburn, S., Zghondi, R., Safe management of wastes from health-care activities, Geneva, World Health Organization (2014)

2. Ferreira, V., Teixeira, M.R.,Waste Management, 30, pp 2657-2663 (2010)

3. Tesfahun, E., Kumie, A., Legesse, W., Kloos, H., Beyene, A., Waste Management Res., 32, pp 15-20 (2014)

4. Wilujeng, S., Damanhuri, E, Chaerul, M., ISWA World Congres 2108, Kuala Lumpur Malaysia, Book of Proceeding. pp 122-127 (2018)

5. Wilujeng, S, Damanhuri, E, Chaerul, M., International Journal of GEOMATE, Vol.16, Issue 55, pp. 34-39, (2019)

6. Wilujeng, S, Damanhuri, E, Chaerul, M., Pollution Research, Vol. 38, pp 35-45 (2019) 